\title{
Rosaï-Dorfman disease
}

INSERM

\section{Source}

INSERM. (1999). Orphanet: an online rare disease and orphan drug data base. RosaïDorfman disease. ORPHA:158014

Rosaï-Dorfman disease is a rare benign non-Langerhans cell histiocytosis characterized by the development of large painless histiocytic masses in the lymph nodes, predominantly of the cervical region. Extranodal involvement can also be observed, such as in the skin, respiratory tract, bones, genitourinary system, soft tissues, oral cavity, and central nervous system. Additional findings may include fever, malaise, epistaxis, night sweats, weight loss, leukocytosis, elevated erythrocyte sedimentation rate and hyperg ammag lobulinemia. 